Jayawardhana, S.K.G.U.K., Hadiwattage, C. and Mahinkanda, M.M.M.P., 2019. Significance of construction technology knowledge for quantity surveyors in expressway construction projects. In: Sandanayake, Y.G., Gunatilake, S. and Waidyasekara, A. (eds). Proceedings of the $8^{\text {th }}$ World Construction Symposium, Colombo, Sri Lanka, 8-10 November 2019, pp. 524-534. DOI: doi.org/10.31705/WCS.2019.52. Available at: https://2019.ciobwcs.com/papers

\title{
SIGNIFICANCE OF CONSTRUCTION TECHNOLOGY KNOWLEDGE FOR QUANTITY SURVEYORS IN EXPRESSWAY CONSTRUCTION PROJECTS
}

\author{
S.K.G.U.K. Jayawardhana ${ }^{1}$, Chandanie Hadiwattage ${ }^{2}$ and \\ M.M.M.P. Mahinkanda ${ }^{3}$
}

\begin{abstract}
The degree of social responsibility of professionals towards public projects are naturally high. Recently, in Sri Lankan context, expressway construction is becoming one of the major public project types. Due to that, the responsibility of professionals towards a successful expressway construction seems very high. Among professionals, Quantity Surveyor $(Q S)$ is a significant team member in any kind of construction project in terms of managing cost and time aspects. Being highly technical and complex, expressway QSS essentially need a significant level of construction technology knowledge to perform the duties and responsibilities. Therefore, the research was focused on investigating the significance of expressway construction technology knowledge for QS practitioners. The scope of the research was narrowed down to Sri Lankan expressway projects. A comprehensive literature review was carried out to identify the duties and responsibilities of QSs in expressway project stages. The research methodology was mixed approached comprising a questionnaire survey and s expert interviews round. Quantitative data analysis was carried out using RII method and qualitative data subjected to content analysis. The research concludes feasibility stage as the most technical knowledge sensitive stage of an expressway construction project with respect to the QS's role. Further, QSs with less experience make projects vulnerable for more cost and time issues due to lack of technical knowledge and such scenarios may add black marks to the role of the QS in big picture, therefore it is essential for the QSS to keep updated with the changing construction technologies.
\end{abstract}

Keywords: Construction Industry; Expressway Construction; Quantity Surveyor; Sri Lanka; Technological Knowledge.

\section{INTRODUCTION}

The construction industry has a significant cultural, environmental, social and economic impact on the country (Loosemore et al., 2018). Technical knowledge of the professionals and workers are valuable assets to any construction organisation (Mohamed and AbouRizk, 2005). Hence, the project team should have a sound level of construction technology knowledge to carry out projects with the use of advanced technologies. Expressway construction is more complex and highly technological than other

\footnotetext{
${ }^{1}$ Currie and Brown International, Sri Lanka, udarajayawa871@gmail.com

2 Department of Building Economics, University of Moratuwa, Sri Lanka, chandanieh@uom.lk

${ }^{3}$ Department of Building Economics, University of Moratuwa, Sri Lanka, mmahinkanda@uom.lk
} 
constructions (Wu et al., 2005). Therefore, the cost management of expressway projects is significant. Among project team members QS is important in such cost aspects which means for value addition for expressway construction. As advisers, QSs estimate and monitor construction costs, from the feasibility stage of a project to the completion of the construction period (Australian Institute of Quantity Surveyors [AIQS], 1998). Being highly technical and complex, expressway QSs required a significant level of construction technology knowledge to perform their duties and responsibilities. AIQS (1998) has identified knowledge of construction technology as a core competency for QS professionals. Further, AIQS (1998) explained that a QS professional, it is compulsory to acquire knowledge of different construction processes, technologies related to construction processes, construction activities, sequencing of activities, erection techniques of plant and equipment, principles of site surveys, interpretation of building plans, construction codes and regulations, source and use of construction materials including testing and assessing techniques. Since QS is involved in almost all the phases of a construction project, he/she needs different levels of construction-related knowledge at different stages of a construction project. Further, it may valid depending upon the QSs role in contractor related and consultant related responsibilities. But in each project stages needs a different level of technical knowledge to perform the role of QS. Due to that, it is necessary to investigate the extent and level of technical knowledge required for QSs in assisting cost management expressway construction projects at different project stages.

\section{LITERATURE SYNTHESIS}

\subsection{Expressway Construction as a Highly Technical Project TYPE}

Expressway construction is a complex project type (Zheng and Chen, 2012). Further, the authors stated that the project programmes subject to heavy changes due to this complexity. There are many types and numbers of activities involved in expressway construction (Arditi and Bentotage, 1996). For instance, when constructing, mechanical and blasting methods are usually utilised, this will cause greater risks. Expressway disciplines consist of various number of technical activities and materials included items such as geometrics and alignment, landscape ecology, earthworks, pavement, retaining walls, slope protection, sound insulation, transportation facilities, drainage, bridges, tunnels, electrical, mechanical, lighting and maintenance (Rooshdi et al., 2014. There is a possibility of being highly technical; the given budget would not be adequate, because quantities of work are not exactly known until the project is completed (Pewdum et al., 2009). Further, it was found that there are factors, which heavily affect to the final budget: traffic volume, topography, weather conditions, evaluating date, contract duration, construction budget, percent of as planned completion, and percent of actual completion, while four (04) factors: work starting date, evaluating date, contract duration, percent of as planned completion, and percent of actual completion are greatly affecting to project duration. Pewdum et al. (2009) further founded that estimation of the road construction cost to be considered with project physical features such as; type of project, project scope, forecasting final budget, construction year, seasons, construction site, project period, project distance, number of lanes, number of streams cutting across the roads, and condition of soil at construction sites. Accordingly, these findings reveal that expressway construction is a highly technical discipline and less knowledgeability on technical aspects may cause adverse cost overruns of the projects. 


\subsection{STAGES OF EXPRESSWAY CONSTRUCTION PROJECTS}

All construction projects pass through a set of common work stages consisting of inception, feasibility, scheme design, detail design, contract formation, construction, and commissioning. Although there may be changes to the sequence and importance of these stages, their identification helps in making judgements about organisational structure on construction projects (Hughes, 1991). In expressway construction various authors have identified different number of project stages for an expressway construction project and few are in the common practice yet. The expressway construction stages in terms of similarities with RIBA plan of work stages are tabulated in Table 1. According to the duties carried out in expressway project in its stages as mentioned by University of Brighton (2016), the comparison with RIBA stages was associated.

Table 1: RIBA Plan of Work vs. expressway construction work stages

\begin{tabular}{|c|c|c|}
\hline $\begin{array}{l}\text { RIBA Work } \\
\text { Stage }\end{array}$ & Core Objectives of Stage of Work & $\begin{array}{l}\text { Expressway Work } \\
\text { Stages }\end{array}$ \\
\hline $\begin{array}{l}\text { Strategic } \\
\text { Definition }\end{array}$ & $\begin{array}{l}\text { Identify client's business requirements and client's } \\
\text { strategic brief and other key project requirements }\end{array}$ & Feasibility study \\
\hline $\begin{array}{l}\text { Preparation and } \\
\text { Brief }\end{array}$ & $\begin{array}{l}\text { Develop objectives of the project, including quality } \\
\text { objectives and outcomes of the project, } \\
\text { sustainability achievements and budget of the } \\
\text { project, other parameters or constraints and develop } \\
\text { first project brief. undertaking feasibility studies } \\
\text { and reviewing site conditions }\end{array}$ & \\
\hline Concept Design & $\begin{array}{l}\text { Prepare concept design, inclusive of outline } \\
\text { proposals for structural design, outline } \\
\text { specifications and basic costing information along } \\
\text { with relevant projects strategies in accordance with } \\
\text { programme for design. Agree or reject alterations to } \\
\text { brief and issue final project brief }\end{array}$ & $\begin{array}{l}\text { Preliminary } \\
\text { engineering Plan }\end{array}$ \\
\hline $\begin{array}{l}\text { Developed } \\
\text { Design }\end{array}$ & $\begin{array}{l}\text { Prepare developed design including coordinated } \\
\text { and updated proposals for structural design, outline } \\
\text { specifications, cost information, and project } \\
\text { strategies in accordance with design programme }\end{array}$ & $\begin{array}{l}\text { Final engineering } \\
\text { Plan }\end{array}$ \\
\hline $\begin{array}{l}\text { Technical } \\
\text { Design }\end{array}$ & $\begin{array}{l}\text { Prepare technical design in accordance with Design } \\
\text { Responsibility Matrix and project strategies to } \\
\text { include all architectural, structural specialist } \\
\text { subcontractor design and specifications, in } \\
\text { accordance with programme of design }\end{array}$ & Construction Plan \\
\hline Construction & $\begin{array}{l}\text { Offsite manufacturing and onsite Construction in } \\
\text { accordance with construction programme and } \\
\text { resolving queries of design from the site as they } \\
\text { arise }\end{array}$ & Construction \\
\hline $\begin{array}{l}\text { Handover and } \\
\text { Close Out }\end{array}$ & Handover of the facility and conclusion of contract & Closeout \\
\hline In Use & $\begin{array}{l}\text { Undertake in use facility in accordance with the } \\
\text { schedule of facility }\end{array}$ & $\begin{array}{l}\text { Maintenance and } \\
\text { Upkeep }\end{array}$ \\
\hline
\end{tabular}

(Sources: Falls et al., 2010; Finnish Transport Agency, 2010; University of Brighton, 2016) 
Although RIBA Plan of Work deals with building construction, it seems that stages in an expressway construction project also can be compared with it. In Table 1, it has been indicated that even though the terms and phrases used in RIBA Plan of Work are different (e.g. Technical design - the $5^{\text {th }}$ stage of RIBA plan, which is called as construction plan in expressway construction stages; yet similar in terms of the activity), the duties carried out in parallel stages of an expressway construction are similar. It can be concluded that despite the project (building or infrastructure) the key duties remain as it is in almost all the novel construction project.

\subsection{TECHNICAL KNOWLEDGE REQUIRED DUTIES AND RESPONSIBILITIES OF A QS IN DIfFERENT PROJect STAGeS}

The activities identified by Herman (2016) in each phase can be mapped with the stages (up to the construction) identified by Falls et al. (2010); Finnish Transport Agency (2010) and University of Brighton (2016) as indicated in Table 2.

Table 2: Mapping expressway project stages defined by various authors

\begin{tabular}{|c|c|}
\hline $\begin{array}{l}\text { Project Stages: Identified by Falls } \text { et al. } \\
\text { (2010); Finnish Transport Agency (2010) } \\
\text { and University of Brighton (2016) }\end{array}$ & $\begin{array}{l}\text { Project Stages: Identified by Herman } \\
\text { (2016) }\end{array}$ \\
\hline Feasibility study & Feasibility stage \\
\hline Preliminary engineering Plan & $\begin{array}{l}\text { Preliminary design and environment } \\
\text { review }\end{array}$ \\
\hline Final engineering Plan & Final design and right-of-way \\
\hline Construction Plan $\}$ & \\
\hline Construction & Post contract stage/ Contraction \\
\hline
\end{tabular}

According to Herman (2016) and Mbachu (2015), the roles of QSs can be seen in five (05) different stages of construction development as shown in Table 3.

Table 3: Summary of construction technology-related duties and responsibilities of QS

\begin{tabular}{ll}
\hline Project stage & \multicolumn{1}{c}{ Duty/Responsibility } \\
\hline Feasibility stage & - Assess transportation purpose and need with the project team \\
& - Gain approval \\
& - Preparation of cost analysis \\
& - Preparation of estimates from sketch to detailed design \\
& - Freparation of cost plan \\
- Vancial feasibility studies including economic & - Preparation of cost-in-use/ life-cycle costing \\
& - Preparation of turnover, profit/loss forecast, and cash-flow \\
& - projections \\
- Cost checking during the development design
\end{tabular}




\begin{tabular}{|c|c|}
\hline Project stage & Duty/Responsibility \\
\hline $\begin{array}{l}\text { Preliminary } \\
\text { design and } \\
\text { environment } \\
\text { review }\end{array}$ & $\begin{array}{l}\text { - Consider alignment issues and required lanes } \\
\text { - Identify alternatives, including not building the project, to } \\
\text { minimise potential harm to the environment and historic sites } \\
\text { - Select preferred alternative } \\
\text { - Preparation of specification and schedule of rates. } \\
\text { - Value management including comparative design economics } \\
\text { - Identify project cost, level of service, and construction location } \\
\text { with the project team } \\
\text { - Prepare a preliminary design of the expressway according to cost } \\
\text { - aspects } \\
\text { - Early-stage comparative cost planning } \\
\text { - Tetailed compilation and analysis of unit rates/ preliminaries } \\
\text { - established or refined by the engineers } \\
\text { - As changes are introduced into the project, to estimate the cost } \\
\text { effectiveness of the change and to report }\end{array}$ \\
\hline $\begin{array}{l}\text { Final design and } \\
\text { right-of-way } \\
\text { acquisition }\end{array}$ & $\begin{array}{l}\text { - Finalise design plans with the project team } \\
\text { - Appraise utilities and affected citizens before construction, if } \\
\text { necessary } \\
\text { - Finalise project cost estimates } \\
\text { - Taking off from detail design } \\
\text { - Advising on the cost of design options } \\
\text { - Analysis and scheduling of work } \\
\text { - Measuring work to define rules } \\
\text { - Preparing cost estimates } \\
\text { - Prepare a financial appraisal }\end{array}$ \\
\hline $\begin{array}{l}\text { Post contract } \\
\text { stage/ } \\
\text { Contraction }\end{array}$ & $\begin{array}{l}\text { - Advertise and evaluate bids; award contracts } \\
\text { - Preparation of contract documents for main contract sub-contracts } \\
\text { - } \text { or contracts of supply including rationalisation of contract rates. } \\
\text { - Evaluating bids } \\
\text { - } \text { Aegin construction } \\
\text { - Application of cost control during the progress of the works. } \\
\text { - Monitoring of proposed construction methods, sequences, and } \\
\text { - } \text { those actually required and reporting thereon. } \\
\text { - Variations and change proposals } \\
\text { - } \text { preparation of cost/benefit reports upon alternative construction } \\
\text { - Thethods } \\
\text { - } \text { contractual issues } \\
\text { - Analysis of contract pricing relative to cost recording methods. } \\
\text { - } \text { reconcilion and/or interpretation of cost/value and other } \\
\text { - Annual budget advice on the construction }\end{array}$ \\
\hline
\end{tabular}




\begin{tabular}{ll}
\hline \multicolumn{1}{c}{ Project stage } & \multicolumn{1}{c}{ Duty/Responsibility } \\
\hline Construction & - Planning and programming of construction activities \\
management & - Site planning \\
and resource & - Liaison with employer, consultants, statutory and service \\
procurement & \\
stage & authorities. \\
& - Resource determination, scheduling, and purchasing. \\
& - Procurement of labour, plant, and materials. \\
& suppliers \\
\hline
\end{tabular}

Sources: Mbachu (2015); Herman (2016)

Technology, common sense and common knowledge regarding technical aspects of the project is highly appreciated in the role of QSs (Lau, 2013). QSs seek to minimise the costs of a project and enhance value for money, while still achieving the required standards and quality (Olubunmi et al., 2014). As Cunningham (2015) mentioned, the professional services carried out by QSs have traditionally included the planning of costs, management of projects from start to completion together with risk analysis and assessment.

\section{RESEARCH METHODOLOGY}

The research question is "What is the extent and level of technical knowledge required by QS in assisting cost management in expressway construction projects at different project stages?". Initially, a comprehensive literature survey was carried out by referring books, journals and other publications to identify technical aspect and QSs technology knowledge requirement in the expressway construction industry. The research further used a mixed research approach in achieving the research objectives comprising a questionnaire survey and expert interviews.

The purpose of the questionnaire survey was to identify the level of QSs competency requirement for technical activities in highway construction. The questionnaire consisted of two sections. The first section was to determine the technological activities, which has the most impact on the QSs role. Purpose of the second section of the questionnaire was to rate the competency level of QSs towards each technical activity. The questions were prepared with the findings of the literature review which highlighted the key duties and responsibilities of a QS in project phases (Table 2). The questionnaires used Likert scale (1-5) and multiple-choice (listed alternative answers) as well. Relative Importance Index (RII) method used to analyse data collected from the Questionnaire Survey. The composition of respondents according to their designation is given in Table 4.

The respondents were selected based on their experience in expressway construction. The sample consisted of different layers and designations of QSs who obtained exposure in Sri Lankan expressway construction projects. The major reason for selecting only the QSs as the sample, since the research focused on QSs' knowledge on expressway construction.

The expert interviews were used to gather views on the causes for lack of technical knowledge, challenges faced by the QSs due to lack of technical knowledge, and the probable strategies to overcome such challenges. 
Table 4: Profile of respondents in questionnaire survey

\begin{tabular}{lccc}
\hline \multicolumn{1}{c}{ Designation } & $\begin{array}{c}\text { Questionnaire } \\
\text { Distributed }\end{array}$ & $\begin{array}{c}\text { Number of } \\
\text { Respondents }\end{array}$ & Response rate \\
\hline Joint Venture (JV) QS & 2 & 2 & $100 \%$ \\
Project QS (PQS) & 10 & 9 & $90 \%$ \\
Senior QS (SQS) & 3 & 3 & $100 \%$ \\
Consultant QS (CQS) & 2 & 2 & $100 \%$ \\
QS & 16 & 14 & $87.5 \%$ \\
Assistant QS & 12 & 10 & $83.33 \%$ \\
\hline
\end{tabular}

\section{RESEARCH FINDINGS}

According to the results of research findings, it has been highlighted that $85 \%$ of the respondents have accepted expressway construction technologies as more complicated and significant than building construction technologies. In the Sri Lankan context, this indication is fare because the expressway construction is new to the country. Building construction has now become very much familiar with the industry practitioners including QSs. Taking everything into account it can be concluded as per findings that, expressway construction technologies as more complex than building construction technologies.

\subsection{SIGNIFICANCE OF KNOWLEDGE REQUIRED By QUANTITY SURVEYORS TO PERForm TeChNOLOGICAL TASKS}

It is important to identify the most significant, expressway construction technical knowledge highly needed project phases as per responses for the questionnaire. It indicates the overall ranking of the main project stages in expressway construction. According to the technical knowledge requirement following is the ranking of expressway construction stages as per the significance.

\section{Rank 1: Feasibility Stage}

Rank 2: Post contract stage/construction stage

Rank 3: Final design and right-of-way acquisition stage

Rank 4: Preliminary design and environment review stage

Rank 5: Accepting project delivery in aspects of cost and time stage

These findings indicate the most technical knowledge required stage when performing tasks in an expressway construction project by QSs is feasibility stage. The least technical knowledge required stage is accepting the project delivery stage. According to the results of the analysis, the top most technology-related knowledge areas identification criteria needed to establish. According to the RII values, if taken the cut off margin as the first quadrant, it selects only a single activity. If second quadrant considered, 23 tasks select as most significant duties. Due to that, first half of the second quadrant (which has RII value more than $85 \%$ ) taken as the cut off margin for a task to become a significant duty among the list of all the construction technology required duties in an expressway construction. It shortlists the significant tasks as in Table 5. 
Table 5: Most technical knowledge required duties or responsibilities of an expressway QS

\begin{tabular}{lll}
\hline \multicolumn{1}{c}{ Duty/responsibility } & \multicolumn{1}{c}{ RII \% } & Rank \\
\hline Preparation of cost analysis & $90 \%$ & 1 \\
Variations and change proposals & $88.5 \%$ & 2 \\
Application of cost control during the progress of the works & $87.5 \%$ & 3 \\
Preparation of turnover, profit/loss forecast, and cash-flow projections & $87 \%$ & 4 \\
Measuring work to define rules & $87 \%$ & 4 \\
The report, evaluating and negotiating on contractual and extra- & $87 \%$ & 4 \\
contractual issues & & \\
Advising on the cost of design options & $86.5 \%$ & 7 \\
Preparing cost estimates & $86 \%$ & 8 \\
Value management/ engineering & $85.5 \%$ & 9 \\
Contractual and tendering arrangements (early advice) & $85.5 \%$ & 9 \\
\hline
\end{tabular}

Among ten most important construction technology-related tasks, four of them were in feasibility stage. The other thing is the topmost factor is also one of feasibility stage tasks. This indicates that the most technical knowledge required in an expressway construction is in initial stages. Without construction technology knowledge QS is unable to perform his/her tasks even at feasibility stage.

However, these significant tasks not indicate that the balance tasks are insignificant. As per the survey conclusion, it summarises that all identified task in the literature is essential to perform duties of QS in each project stages in different knowledge levels.

\subsection{Challenges due to PoOR Technology KNOWledge OF QSS AND STRATEGIES TO OVERCOME THEM}

As a key finding of the expert interviews, it was indicated that, if there is a poor technological background relevant to expressway construction by QS personally or their representative organisations, there can be many issues. Those underlying causes for lacking technical knowledge of QSs in expressway construction are listed below.

- Less experience in road construction

- Difficulty to find QSs with a proper level of technical knowledge

- Lacking educational syllabus coverage regarding expressway construction for QSs

- Less collaboration within the project team

- Fewer expressway projects available in the local context

Considering all the expert views, it can be concluded that there are challenges faced by QS personally or their representing organisations if there is a poor technological background relevant to expressway construction by QSs as listed below.

- Failure to evaluate different technical design options in terms of cost and time

- The hidden role of QSs and the advice given by the QSs might get rejected

- A disgrace to the profession and representing organisation

- Failures to the role of QS within the project team

- Inability to evaluate claims and variations

- Difficulties of reading construction drawings 
- Increased risk of cost overruns and time overruns

- Inability to identify risks

From the expert interviews, the suggested strategies to overcome from challenges caused by the lack of construction technology are as follows.

- Educate on technology continuously (CPDs, Syllabus revisions)

- Analyse the case properly

- Improve the presentation system

- Well conversion with project documents

- Share knowledge among the team

- Self-learning from reading materials

- Good communication with other team members

- The assistance provides by experienced QSs

- Peer learning

- Developing competencies over application of the knowledge

\section{CONCLUSIONS}

It was identified that, when performing the role of QS, the knowledge regarding construction technology as essential. Even though as QSs it has been established that construction technology is a key competency of professional previous studies has not focused especially on expressway construction technologies despite playing this knowledge a major role in terms of cost impacts in the project. However, the required technology to perform knowledge level for each duty/ responsibility of QS in different stages of an expressway construction project varies. The primary focus of this study was to investigate the significance of technical knowledge for QS in assisting cost management in Expressway construction projects in Sri Lanka as a means of achieving successful project outcomes.

Mainly the technical aspect of expressway construction highlights its complexity compared to building construction. Being highly technical, from the initial stages of the project, the technical nature of stages can be seen. For completing a new major expressway project takes a number of years due to many tasks, requirements, approvals, and stakeholders. The expressway project stages are different from building project stages. Hence, RIBA Plan of Work is unable to apply for expressway construction and a different number of stages were defined. However, it can be mapped to expressway project stages with RIBA Plan of Work. The stages consist of feasibility stage, preliminary design and environmental review stage, final design and right of way stage, construction stage and resource management stage. The technical activities in each stage are different from one another.

There are criticisms of expressway projects due to not achieving project goals properly. Project delivery is not within a reasonable amount of time and finally, costs are not in line with the budgets. There is a possible contribution from QS towards avoiding criticisms. Hence, performing duties well in the project is required by expressway QSs. The role of QS in stages of expressway construction to be highlighted in terms of technology requirement.

For almost all the activities performed by QS, in each stage of an expressway construction, the technical knowledge is a must. According to the findings, the highest 
technical incentive required activities were preparation of cost analysis, variations and change proposals and application of cost control during the progress of the works. Highly technical knowledge required stage. With that, ranking stages as per level of technical knowledge need are; Feasibility Stage, Post contract stage/construction stage, Final design and right-of-way acquisition stage, Preliminary design and environment review and Accepting project delivery (in aspects of cost and time) in order. As per the requirement, QS should have relevant level of knowledge on construction activities when performing QS duties.

Due to lack of technical knowledge for such complex technological project, the challenges faced were identified as; the inability of paraphrasing design options in terms of cost and time, incapacity to convince the project team regarding cost, time and quality aspects and incompetence to identify risks. Apart from that disgrace to the profession and representing organisation, fails within the project team, inability to evaluate claims and variations, inability to read construction drawings, cost overrun and time overrun is the rest of challenges face due to lack of technological knowledge.

The key reasons for lack of technical knowledge for QSs were; less experience in road construction, difficulty to find QSs with proper knowledge, no syllabus regarding expressway construction for QSs, less collaboration in between the project team a and finally fewer expressway projects available in local context. As a major reason, Sri Lanka is still new to expressway construction. With regard to that the opportunities created for involving as an expressway construction was less. The solutions for this issue needed for overcoming from the undelaying causes.

In terms of contribution to the industry through this research, it is apparent that since this research have identified the priority of stages of the expressway construction project in terms of construction technology requirement for QSs. Based on that QSs can pay required level of attention for technological aspect when performing tasks at each project stage. Also the study identified that QSs should have sound technical knowledge on expressway construction technologies to perform assigned duties. Therefore, the study recommends the governing bodies to conduct CPDs for highway construction technologies due to still it is new to Sri Lanka. Finally, the study investigated the strategies to overcome challenges, which have been created based on QSs lack of technical knowledge, in the practical aspect also. If practitioners faced with similar challenges as identified in the research can follow the proposed strategies.

However, this research paves the way for future research directions such as;

- Since the current study was limited to QSs construction knowledge area and generalised it. Further research can be carried out for consultant QSs and contractor QSs separately

- QSs' construction technology knowledge required to perform tasks in feasibility stage of construction projects

\section{REFERENCES}

Arditi, D. and Bentotage, S. N., 1996. System for Scheduling Highway Construction Projects. ComputerAided Civil and Infrastructure Engineering, 11(2), pp.123-139.

Australian Institute of Quantity Surveyors [AIQS], 1998. Competency standards for Quantity Surveyors Construction Economists and Cost Engineers, Sydney: AIQS. 
Cunningham, T., 2015. Cost Control during the Pre-Contract Stage of a Building Project-An Introduction. Report prepared for Dublin Institute of Technology.

Falls, T., Thomasen, J., Clinckett, J., Molyneux, D., Youmans , A., Fillingham, C. and Lesurf, C., 2010. A Guide to Project Closeout Procedures, Ontario: Ontario General Contractors Association and Ontario Association of Architects.

Finnish Transport Agency, 2010. Road Planning Process. [Online] Available at: https://www.liikennevirasto.fi/web/en/_[Accessed 31 January 2018].

Herman, S., 2016. The Motivation of Quantity Surveyors in the Malaysian Construction Industry for Improved Job Performance. Salford: The University of Salford.

Hughes, W., 1991. Modelling the construction projects using plans of work. In: Proceedings of International Conference CIB W65, Dubrovnik, Yugoslavia, pp. 81-86.

Lau, E., 2013. An Investigation of the Role of QS in Infrastructure Projects, City University of Hong Kong.

Loosemore, M., Lim, B. T. H., Ling, F. Y. Y. and Zeng, H. Y., 2018. A comparison of corporate social responsibility practices in the Singapore, Australia and New Zealand construction industries. Journal of Cleaner Production, pp.140-150.

Mbachu, J., 2015. Quantity Surveyors' Role in the Delivery of Construction Projects: A Review. Quantity Surveyors (NZIQS), 25.

Mohamed, Y. and AbouRizk, S., 2005. Technical Knowledge Consolidation using Theory of Inventive Problem Solving. Journal of Construction Engineering and Management, 131(9), pp.993-1002.

Olubunmi, O.A., Timothy, I.O., Alabi, A.O. and Israel, O.T., 2014. Competitive strategies of selected quantity surveying firms in Nigeria. International Journal of Management, Information Technology and Engineering, 2(11), pp.1-18.

Pewdum, W., Rujirayanyong, T. and Sooksatra, V., 2009. Forecasting final budget and duration of highway construction projects. Engineering, Construction and Architectural Management, 16(6), pp.544-557.

Ritchie, J., Nicholls, C. and Ormston, R., 2014. Qualitative Research Practice. $2^{\text {nd }}$ ed. London: Sage Publications.

Rooshdi, R.R.R.M., Ab Rahman, N., Baki, N.Z.U., Majid, M.Z.A. and Ismail, F., 2014. An evaluation of sustainable design and construction criteria for green highway. Procedia Environmental Sciences, 20, pp.180-186.

University of Brighton, 2016. Project Workstages and Procedures Checklist. [Online] Available at: https://staff.brighton.ac.uk/efm/Public_Docs/pm_framework_03_08_15.pdf [Accessed 31 January 2018].

Wu, C. H., Hsieh, T. and Cheng, W.1., 2005. Statistical analysis of causes for design change in highway construction on Taiwan. International Journal of Project Management, 23(7), pp.554-563.

Zheng, S. and Chen, J., 2012. The Study of The Core Concept of Safety Culture in Highway Engineering Construction Projects. Systems Engineering Procedia, 4, pp.460-467. 